\title{
Screening and Identification of Soy Curd-Producing Lactic Acid Bacteria
}

Ro-Ui Kim', Soon-Cheol Ahn², Sun-Nyoung Yu², Kwang-Youn Kim², Jong-Hwan Seong', Young-Guen Lee ${ }^{1}$, Han-Soo Kim ${ }^{1}$ and Dong-Seob Kim*

${ }^{1}$ Department of Food Science \& Technology, Pusan National University, Miryang 602-706, Korea

${ }^{2}$ Department of Microbiology and Immunology, Pusan National University School of Medicine, Yangsan 626-870, Korea

Received October 15, 2010 /Accepted December 1, 2010

\begin{abstract}
The purpose of this study was to isolate soy curd forming bacterial strains. Soy curd forming bacteria were isolated from Kimchi, a traditional Korean vegetable food that is fermented using lactic acid bacteria. Among 196 bacterial strains, ten isolates (strain No. 2-2-2, 2-15-2, 2-18-1, 2-19-2, 3-4-1, 3-4-2, 3-8-1, 3-8-3, 3-17-1, 4-39-5) formed firm soy curd. The isolated bacterial strains were identified by molecular biological and biochemical analyses. The genomic DNAs extracted from the isolated bacterial strains were used as a template for PCR amplification of 16S rDNA region. By comparing the results of the 16s rDNA sequences with GenBank data, the isolated strains were identified as Leuconostoc mesenteroides group and Lactobacillus sakei group. The phylogenetic position of soy curd forming strains and their related taxa were investigated using neighbor-joining method. L. mesenteroides group was further identified as L. mesenteroides subsp. dextranicum based on biochemical properties. L. sakei group was named Lactobacillus sp., because it showed a variety of biochemical properties.
\end{abstract}

Key words : Soy curd, lactic acid bacteria, identification

\section{서 론}

현대인들의 패스트 푸드, 육류 섭취의 증가로 인한 식생활 의 변화가 비만증, 동맥경화증, 당뇨병과 같은 성인병을 증가 시키는 심각한 문제로 대두되고 있다. 따라서 동물성 식품을 대체하기 위한 다양한 식물성 식품을 개발하고자 하는 연구가 활발히 진행되고 있다.

식물성 유래 식품의 대표인 콩은 다양한 생리활성 물질을 가지고 있어서 현대인의 성인병 예방에 중요한 역할을 하고 있다 $[5,12,13]$. 미국 식품의약안전국 $(\mathrm{FDA})$ 은 하루 콩 단백질 $25 \mathrm{~g}$ 이상을 섭취하면 심장질환의 발생 위험을 줄일 수 있다고 보고하였으며[15], 미국인보다 약 20-50 배 정도 더 많은 대두 를 섭취하는 아시아 국가들은 유방암과 전립선암의 발병률이 낮은 것으로 연구되었다[8,17]. 콩은 영양가가 높다고 알려져 있는 반면, 소화율이 낮고 콩 비린내를 유발하는 lipoxygenase 와 위와 장에서 gas를 생산하는 trypsin inhibitor, phytic acid 등이 함유되어 있어서 이를 개선하기 위해 콩을 발효하는 가 공법이 시도되고 있다[9].

한편 유산균은 자연계에 널리 분포하며 여러 가지 식품을 발효시키는데, 특히 김치 유산균의 경우 혈중 콜레스테롤 저 하, 면역 증강, 항암, 정장효과 등이 알려져 있다[20]. 요구르트 는 단백질과 지방의 소화 흡수를 증진시키고, 유당의 소화를

*Corresponding author

Tel : +82-55-350-5356, Fax : +82-55-350-5359

E-mail : dskim1961@hotmail.com
돕고[10], 혈중 콜레스테롤을 저하시키며[11], 세균성 식중독 억제[2], 항암작용[18] 등을 나타내는 것으로 알려져 있다. 특 히 유산균은 탈지 두유보다는 두유에서 우수한 생육을 보였으 며[14], 두유에 유산균을 배양하면 생리 기능적 측면에서도 여 러 가지 유효활성이 향상되는 것으로 보고되고 있다. 대표적 인 예로써 항산화 활성 증가[19], 유산균의 $\beta$-glucosidase 활성 에 의하여 대두 isoflavone 무배당체가 체내 흡수 속도가 빠른 isoflavone 무배당체(특히 daidzein, genistein, glycitein)로의 형태로 전환되며[3,4] $\gamma$-aminobutyric acid (GABA)와 유리 아미노산의 함량이 증가하는 것으로 알려져 있다[16].

발효된 두유는 우유보다 경제적이며 고단백의 높은 영양적 가치를 제공하는 이점을 가지고 있다[6]. 그러나 점차 다양해 지고 있는 소비자의 요구와는 상반되게 시중에 판매되고 있는 요구르트의 형태는 우유를 이용한 액상 요구르트가 대부분이 다. 액상형태의 요구르트와는 달리 curd 형태의 생산물은 영 양학적 가치 외에도 치료적인 측면에서 개발되어 왔다[1]. 따 라서 curd 형태의 두유 요구르트가 건강식품으로서 개발 할 가치가 충분하다고 사료되어 두유를 순두부 형태의 식물성 요구르트로 만들고자 김치 유래 젖산균으로부터 두유를 curd 형태로 만드는 균을 분리하고 동정하였다.

\section{재료 및 방법}

시료

부산 지역의 가정에서 수거한 김치 국물 시료 56 개를 $-20^{\circ} \mathrm{C}$ 
에 보관하며 사용하였다. 멸균 증류수에 김치 국물을 적절한 배수로 희석한 뒤 MRS (Becton, Dickinson and Company, $\mathrm{New}$ Jersey, USA) 한천 평판배지에 도말하여 $37^{\circ} \mathrm{C}$ 에서 24 시 간 평판배지에서 서로 다른 형태의 균락을 분리하였다.

\section{젖산균의 분리}

국산대두 $100 \mathrm{~g}$ 과 증류수 $1,000 \mathrm{ml}$ 를 두유제조기 (NSM-6200, 엔유씨전자, 대구, 한국)에 넣어 두부 기능(33 분) 을 작동시키고 게르마늄 컵에 거름망 안에 비지를 제외한 두 유를 $50 \mathrm{ml}$ 씩 넣어 $40 \sim 45^{\circ} \mathrm{C}$ 로 식혔다. MRS 액체배지에 $37^{\circ} \mathrm{C}$ 에서 24 시간 배양한 196 개의 김치 유래 분리균주 배양액 $100 \mu \mathrm{l}(0.2 \%)$ 를 준비한 두유에 접종하고 $37^{\circ} \mathrm{C}$ 에서 18 시간 배양하여 curd를 형성하는 균주들을 선별하였다.

\section{분리균주의 분자생물학적 분석}

두유에서 curd를 형성하는 균주를 MRS 액체배지에서 $37^{\circ} \mathrm{C}$ 에서 24 시간 동안 배양하여 Bacterial Genomic DNA Purification Kit (Dokdo-Prep, ElpisBiotech. Inc., Taejeon, Korea)를 사용하여 genomic DNA를 추출하였다. $16 \mathrm{~s} \mathrm{rDNA}$ 의 gene은 thermal cycler (My CyclerTM thermal cycler, Bio-Rad, California, USA)를 이용하여 증폭시켰다. 실험을 위 한 PCR mixture는 20 pmol oligonucleotide primer bact_f (5'-AGAGTTTGATCCTGGCTCAG-3') $1 \mu 1$ 와 20 pmol bact_r (5'-ACGGCTACCTTGTT ACGACTT-3') $1 \mu \mathrm{l}$, Taq polymerase (ElpisBiotech. Inc., Taejeon, Korea) 1U, 2.5mM deoxynucleoside triphosphate (Labo Pass, COSMO co, Ltd., Seoul, Korea) $1 \mu$, Taq polymerase를 위한 10× buffer $2 \mu$, 멸균증류 수 $14 \mu \mathrm{l}$, 주형 DNA $1 \mu \mathrm{l}$ 를 넣어 혼합하였다. 16s rDNA의 gene은 thermal cycler (My CyclerTM thermal cycler, Bio-Rad, California, USA)를 이용하여 증폭시켰다. 조건은 $95^{\circ} \mathrm{C}$ 에서 initial denaturation시킨 다음 30 cycle로 $95^{\circ} \mathrm{C}$ 에서 1 분 동안 denaturation, $60^{\circ} \mathrm{C}$ 에서 1 분 동안 annealing, $72^{\circ} \mathrm{C}$ 에서 1 분 동안 extension하고 마지막으로 $72^{\circ} \mathrm{C}$ 에서 10 분 동안 extension 시키 고 $4^{\circ} \mathrm{C}$ 에서 보관하였다.

염기서열은 Genetyx program으로 pairwise alignment를 하여 GenBank의 BLAST database에서 표준 균주의 DNA 크 기가 1,200 bp 이상인 신뢰성 있는 데이터만을 선별하여 sequence match하였다. Genetyx program과 Bioedit program을 이용하여 선별 균주와 표준 균주의 염기서열간의 multi-alignment를 수행하여 상동성을 비교하고, Bioedit program과 Mega software ver. 4.0을 이용하여 phylogenetic tree를 작성 하였다. Distance option은 Kimura 2-parameter를 이용하였고 replication은 1,000 번하여 Neighbor-joing tree를 작성하였다.

\section{분리균주의 생화학적 분석}

API 50 CHL kit (bioMérieux sa, Marcy-l'Etoile, France)를
사용하여 선별균주를 대상으로 49 종의 탄수화물에 대한 발효 능을 확인하였다. 선별균주를 MRS 액체배지에 $30^{\circ} \mathrm{C}$ 에서 24 시간 배양한 뒤 스트립 튜브에 분주하여 $30^{\circ} \mathrm{C}$ 에서 48 시간 동안 호기적으로 배양하였다. 실험 결과는 동정용 프로그램 $\mathrm{Apiweb}^{\mathrm{TM}}$ 에서 확인하거나 Bergey's manual을 참고하였다.

$\mathrm{CO}_{2}$ 생성을 확인하기 위하여 시험관에 MRS 액체배지 5 $\mathrm{ml}$ 을 넣고 기포가 생기지 않게 Durham tube을 넣은 다음 12 $1{ }^{\circ} \mathrm{C}$ 에서 15 분간 멸균하였다. 선별된 균주를 준비된 시험관에 접종한 뒤 $30^{\circ} \mathrm{C}$ 에서 48 시간 배양하여 Durham tube 내의 기포 발생 여부를 확인하였다.

\section{분리균주의 형태학적 분석}

Gram staining하기 위하여 slide glass에 선별된 균주를 약 한 불로 고정하여 crystal violet 시약으로 1 분간 염색한 뒤 세척하고, $\mathrm{Gram}^{\prime}$ iodine을 1 분간 처리하여 세척하였다. 마지 막으로 $95 \%$ 에탄올로 10 20 초 동안 탈색한 다음 세척하여 현미경으로 관찰하였다.

전자현미경으로 균의 형태를 관찰하기 위해서 1 시간 동안 $2.5 \%$ glutaraldehyde로 1 차 고정하고 1 시간 동안 $1 \%$ osmium teroxide로 2 차 고정을 한 뒤, 10 15 분 동안 에탄올 $(50,70,90,95 \%)$ 을 이용하여 단계별로 탈수하고 $100 \%$ 에탄올 로 10 분씩 2번 탈수하였다. Hexametyldisilazane (HMDS)으 로 10 분씩 2 번 처리하여 시료를 air-dry한 후, 이온중착기 (hitachi E-1010, Japan)를 이용하여 백금이나 금으로 코팅하고 Scanning electron microscope (SEM, hitachi S-3500N, Japan) 으로 관찰하였다.

\section{분리 균주의 whole cell protein의 특성}

선별된 균주를 $\mathrm{MRS}$ 액체배지에 접종하여 $30^{\circ} \mathrm{C}$ 에서 24 시 간 배양한 후, $1 \mathrm{ml}$ 을 $13,000 \mathrm{rpm}$ 으로 1 분간 원심분리하여 침전물을 멸균증류수로 2 번 세척하고 멸균 증류수 $200 \mu 1$ 를 넣어 초음파세포분쇄기(Sonics \& Materials INC., Newtown, USA)를 이용하여 단백질을 추출하였다.

선별 균주로부터 단백질을 추출한 시료를 $13,000 \mathrm{rpm}$ 으로 30 초간 원심분리하고 상등액 $100 \mu 1$ 에 5× loading buffer (250 $\mathrm{mM}$ Tris-HCl, pH 6.8, 0.5 M DTT, 10\% SDS, 0.5\% bromophenol blue, $50 \%$ glycerol)를 $20 \mu \mathrm{l}$ 첨가하여 $12 \%, 15 \%$ polyacylamide gel에 각 시료 $30 \mu \mathrm{l}$ 씩 loading하고 전기영동하였 다. 전기영동이 끝난 뒤 $0.05 \%$ Coomassie brilliant blue R-250 (Bio-Rad Laboratories, Richmond, USA)로 2 시간 동안 염색 하고 destaining buffer I ( $40 \%$ methanol $160 \mathrm{ml}, 10 \%$ acetic acid $40 \mathrm{ml}$ ), destaining buffer $\Pi$ (methanol $5 \% 20 \mathrm{ml}$, acetic acid 7\% $28 \mathrm{ml}$ )로 순차적으로 탈색하여 Sodium dodecyl sulfate-polyacylamide gel electrophoresis (SDS-PAGE)에서 나 타나는 단백질 band를 분석하였다. 


\section{결과 및 고찰}

\section{두유 curd 형성 균주의 분리}

김치로부터 분리하여 균락의 색깔, 모양이 서로 다른 196 개의 단일 균주 중 10 개의 균주(strain No. 2-2-2, 2-15-2, 2-18-1, 2-19-2, 3-4-1, 3-4-2, 3-8-1, 3-8-3, 3-17-1, 4-39-5)에서 순 두부와 같이 비교적 단단한 두유 curd를 형성하였다(Fig. 1A). 10 개의 균주를 제외한 다른 균주들은 두유에 접종 시 무른 curd가 형성되거나(Fig. 1B), 두유의 위층에 막이 형성되면서 그대로 부패되는 것이 관찰되었다(Fig. 1C).

\section{두유 curd 형성 균주의 분자생물학적 분류와 동정}

두유 curd를 형성하는 10 개의 균주(strain No. 2-2-2, 2-15-2, 2-18-1, 2-19-2, 3-4-1, 3-4-2, 3-8-1, 3-8-3, 3-17-1, 4-39-5)

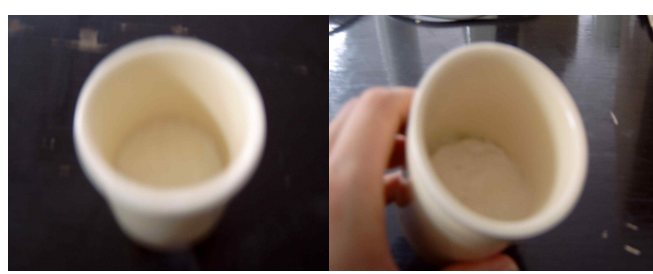

(A)

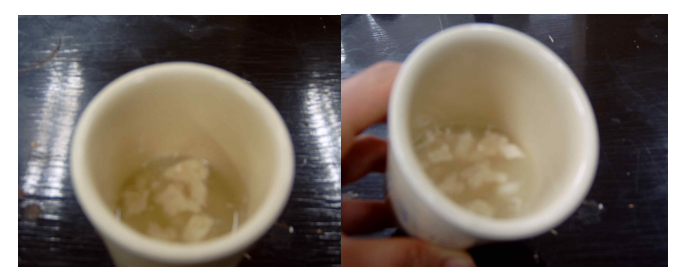

(B)

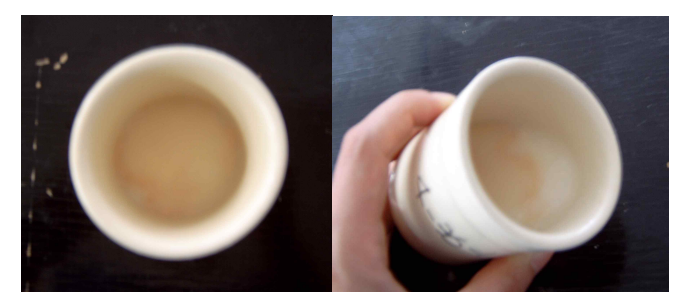

(C)

Fig. 1. Soy curds formed by bacteria isolated from Kimchi. (A) strain No. 4-39-5 (hard-curd), (B) strain No. 3-12-2 (soft-curd), (C) strain No. 4-36-4 (pseudo-curd)
에서 얻어진 genomic DNA를 template으로 하여 $16 \mathrm{~S} \mathrm{rDNA}$ 를 $\mathrm{PCR}$ 한 결과 $1.5 \mathrm{~kb}$ 의 $\mathrm{PCR}$ 산물을 얻을 수 있었다(data not shown). 선별 균주와 표준 균주의 $16 \mathrm{~S} \mathrm{rDNA}$ 염기서열간 의 상동성을 비교한 결과, 선별된 균주들은 Leuconostoc mesenteroides와 Lactobacillus sakei 등 2개의 group으로 동정되었다 (Table 1).

그러나 L. sakei group와 선별된 4 개의 균주(strain No. 2-2-2, 3-8-1, 3-8-3, 3-17-1)의 homology는 99 100\%로 나타났 으나, L. sakei subsp. carnosus, L. sakei subsp. sakei 등과 같이 $16 \mathrm{~S} \mathrm{rDNA}$ 염기서열들간의 차이가 나타나지 않아 아종 수준 의 정확한 동정이 되지 않았다(Fig. 2). 또한 L. mesenteroides group (strain No. 2-15-2, 2-19-2, 2-18-1, 3-4-1, 3-4-2, 4-39-5)의 경우에도 L. mesenteroides subsp. cremoris, L. mesenteroides subsp. dextranicum등 아종 간의 $16 \mathrm{~S} \mathrm{rDNA}$ 에 의한 염기서열 들의 차이가 거의 없거나 전혀 없는 경우가 많아 구별이 쉽지 않을 뿐만 아니라 L. mesenteroides 가 Lactococcus lactis, Leuconostoc kimchi 등과도 비슷한 염기서열로 되어있어 정확 한 균주의 동정을 위해 분자생물학적인 방법 이외의 추가 실 험이 필요하였다.

\section{두유 curd 형성 균주의 생화학적 분류와 동정}

분리된 균주들을 분류, 동정하기 위해 API test를 한 결과, $16 \mathrm{~S} \mathrm{rDNA}$ 염기서열분석에서 L. mesenteroides로 동정된 선별 균주의 경우, Table 2와 같이 API test 결과 strain No. 2-19-2에 서 보여지는 일부 탄수화물 발효 양상을 제외하고는 대체적으 로 일치하여 API test로도 비교적 정확한 동정이 가능하였다. 반면에 $16 \mathrm{~S} \mathrm{rDNA}$ 에 의한 염기서열분석에서 L. sake로 확인된 선별 균주의 경우에는 rhamnose, mannitol, a-methyl-D-glucoide, salicin, maltose, trehalose, affinose, gentiobiose 등의 탄수화물 발효 양상에서 차이를 보여 분자생물학적 결과와 API test가 일치하지 않았으며(Table 3), API $50 \mathrm{CHL}$ 에서 확인 할 수 있는 균주 목록에 포함되어 있지 않음을 확인할 수 있었 다. 동일 균주일 경우에도 상태에 따라 탄수화물 발효가 일어 나는 조건이 조금씩 다름을 고려해 본다면 API test만으로 10 개의 선별 균주가 모두 다른 균주라고 단정짓는 것은 어려울 것이라 사료된다. 김치 젖산균의 경우 대표적인 몇몇의 균 이 외의 균들은 연구가 많이 행해지지 않았으며 표준화된 동정방 법이 부족한 실정이며 최근 일부 연구에서 API test로 동정되

Table 1. List of identified isolate strains by $16 \mathrm{~S}$ rDNA analysis

\begin{tabular}{clcc}
\hline Strain No. & \multicolumn{1}{c}{ Closest relative } & $\%$ Identity & Gene bank accession number \\
\hline $\begin{array}{l}2-15-2,2-18-1, \\
2-19-2,3-4-1 \\
3-4-2,4-39-5\end{array}$ & Leuconostoc mesenteroides & $99 \sim 100 \%$ & GQ351322 \\
\cline { 2 - 4 } $\begin{array}{l}\text { 2-2-2, 3-8-1, } \\
3-8-3,3-17-1\end{array}$ & Lactobacillus sakei & $99 \%$ & GU130195 \\
\hline
\end{tabular}




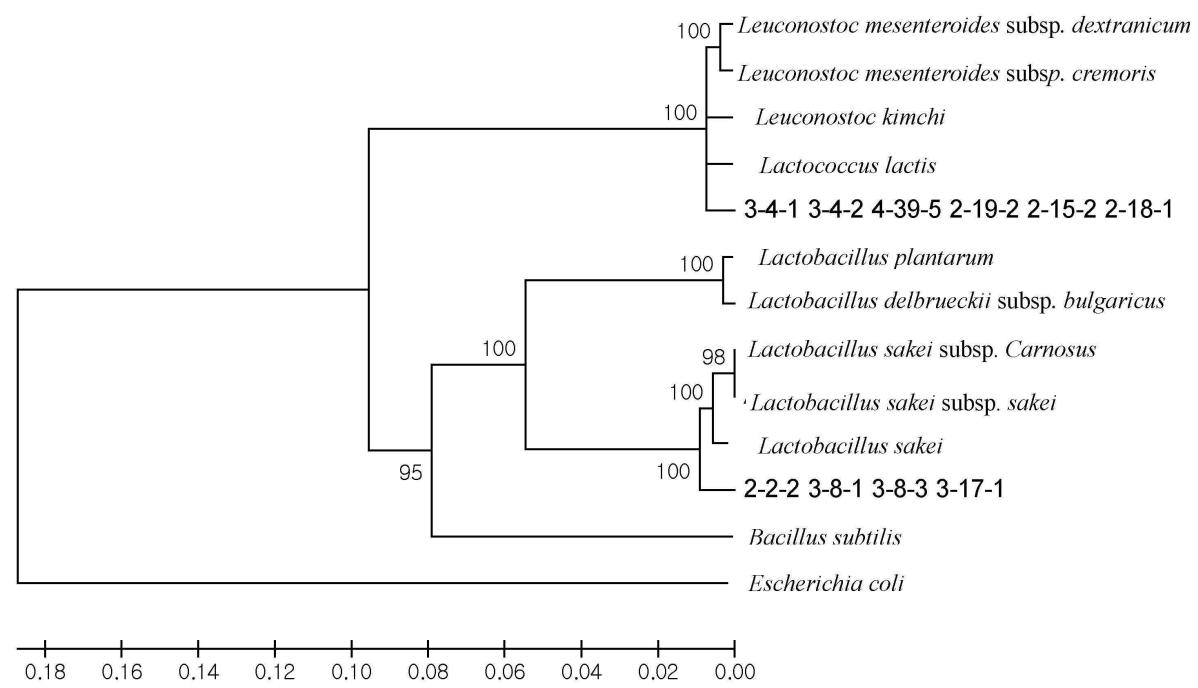

Fig. 2. Phylogenetic tree based on $16 \mathrm{~S}$ rDNA sequences of isolate strains. The branching pattern was generated by the neighbor-joining method. Bootstrap values are expressed as percentage of 1,000 replicates. The sequence of Escherichia coli served as outgroup sequence.

Table 2. Characteristics of carbohydrate fermentation of isolate strains by API $50 \mathrm{CHL}$

\begin{tabular}{|c|c|c|c|c|c|c|c|c|c|c|}
\hline \multirow[b]{2}{*}{ Carbohydrates } & \multicolumn{6}{|c|}{ L. mesenteroides } & \multicolumn{4}{|c|}{ L. sakei } \\
\hline & 1 & 2 & 3 & 4 & 5 & 6 & 7 & 8 & 9 & 10 \\
\hline L- Arabinose & + & + & $+{ }^{W}$ & + & + & + & + & + & + & + \\
\hline Ribose & $+{ }^{W}$ & $+\mathrm{W}$ & $+{ }^{W}$ & $+{ }^{W}$ & $+{ }^{\mathrm{W}}$ & $+{ }^{W}$ & + & + & + & + \\
\hline D-Xylose & $+{ }^{\mathrm{W}}$ & $+{ }^{\mathrm{W}}$ & $+{ }^{W}$ & $+{ }^{w}$ & $+{ }^{\mathrm{W}}$ & $+{ }^{W}$ & - & $+{ }^{\mathrm{W}}$ & - & - \\
\hline Rhamnose & - & - & - & - & - & - & - & + & $+{ }^{W}$ & $+{ }^{\mathrm{W}}$ \\
\hline Mannitol & $+{ }^{\mathrm{W}}$ & $+{ }^{\mathrm{W}}$ & $+{ }^{w}$ & $+{ }^{w}$ & $+{ }^{\mathrm{W}}$ & $+{ }^{w}$ & - & + & - & - \\
\hline a-Methyl-D-glucoiode & + & + & + & + & + & + & + & - & + & - \\
\hline Amygdaline & $+{ }^{\mathrm{W}}$ & $+{ }^{\mathrm{W}}$ & + & + & - & + & - & - & $+{ }^{\mathrm{w}}$ & - \\
\hline Arbutine & $+{ }^{W}$ & $+{ }^{W}$ & + & + & + & + & - & $+{ }^{\mathrm{W}}$ & - & - \\
\hline Salicin & + & + & + & + & + & + & - & + & + & $+{ }^{W}$ \\
\hline Cellobiose & $+{ }^{w}$ & $+{ }^{W}$ & + & + & - & + & + & + & + & + \\
\hline Maltose & + & + & + & + & + & + & + & + & - & - \\
\hline Lactose & $+{ }^{w}$ & $++^{W}$ & - & + & - & + & $+{ }^{W}$ & + & + & $+{ }^{\mathrm{w}}$ \\
\hline Trehalose & + & + & + & + & + & + & - & + & + & + \\
\hline Raffinose & + & + & + & + & + & + & - & + & - & - \\
\hline Gentiobiose & $++^{w}$ & $+{ }^{W}$ & + & + & - & $+{ }^{W}$ & - & + & + & + \\
\hline D-Turanose & + & + & + & + & + & + & - & + & - & - \\
\hline Gluconate & $+{ }^{W}$ & $+{ }^{\mathrm{W}}$ & $+{ }^{W}$ & $+{ }^{W}$ & $+{ }^{\mathrm{W}}$ & $+{ }^{W}$ & $+{ }^{\mathrm{W}}$ & + & + & $+{ }^{W}$ \\
\hline 2 Keto-gluconate & - & - & $+{ }^{W}$ & - & $+{ }^{W}$ & $+{ }^{W}$ & - & $+{ }^{W}$ & - & - \\
\hline 5 Keto-gluconate & $+{ }^{w}$ & $+{ }^{\mathrm{W}}$ & $+{ }^{W}$ & $+{ }^{W}$ & $+{ }^{W}$ & - & - & - & - & - \\
\hline
\end{tabular}

+ : positive, $+^{\mathrm{W}}$ : weak positive, -: negative

1: strain No. 3-4-1, 2: strain No. 4-39-5, 3: strain No.2-18-1, 4: strain No. 2-15-2, 5: strain No. 2-19-2, 6: strain No. 3-4-2, 7: strain No. 2-2-2, 8: strain No. 3-17-1, 9: strain No. 3-8-3, 10: strain No. 3-8-1

지 않는 젖산균이 상당수 존재하는 것으로 밝혀졌다[7]. 또한 김치 젖산균의 경우 동정 기준이 모호하고 균의 특성에 대한 연구가 부족하여 동정하는데 어려움이 많은 것으로 여겨진다. 특히 L. sakei의 경우 API test로도 확인할 수 없는 균주임을
감안할 때 젖산균의 탄수화물 발효연구와 같은 생화학적 방법 의 연구가 더 많이 이루어져야 하며, 앞으로 명확한 젖산균 동정을 위한 분자 생물학적 동정과 생화학적 분석이 필요할 것으로 여겨진다. 
Table 3. Identification of isolate strains by API $50 \mathrm{CHL}$ and $16 \mathrm{~S}$ rDNA analysis

\begin{tabular}{cll}
\hline \multicolumn{1}{c}{ Strain No. } & \multicolumn{2}{c}{ Identification results } \\
\cline { 2 - 3 } $\begin{array}{l}2-15-2,2-18-1,2-19-2,3-4-1, \\
3-4-2,4-39-5\end{array}$ & $\begin{array}{l}\text { Leuconostoc mesenteroides } \\
(99 \sim 100 \%)\end{array}$ & $\begin{array}{l}\text { Leuconostoc mesenteroides } \\
\text { subsp. mesenteroides /dextranicum } \\
(82 \sim 99.7 \%)\end{array}$ \\
\hline $2-2-2,3-8-1,3-8-3,3-17-1$ & $\begin{array}{l}\text { Lactobacillus sakei } \\
(99 \sim 100 \%)\end{array}$ & $\begin{array}{l}\text { Lactobacillus plantarum }(88.6 \%) \\
\text { Lactobacillus lactis subsp. lactis }(79 \%) \\
\text { Lactobacillus brevis }\end{array}$ \\
\hline
\end{tabular}

$\mathrm{CO}_{2}$ 생성 실험에서는 $\mathrm{API}$ test와 $16 \mathrm{~S} \mathrm{rDNA}$ 동정에서 $L$. mesenteroides로 확인되었던 6개의 균주(strain No. 2-15-2, 2-19-2, 2-18-1, 3-4-1, 3-4-2, 4-39-5)에서 모두 $\mathrm{CO}_{2}$ 가 활발하게 발생하였다(data not shown). 한편, $16 \mathrm{~S} \mathrm{rDNA}$ 를 이용한 동정 에서 L. sakeiᄅ로 확인된 균주 중 strain No. 3-8-1, 3-17-1은 $\mathrm{CO}_{2}$ gas가 생성되지 않은 반면, strain No. 2-2-2, 3-8-3의 경우 소량 의 $\mathrm{CO}_{2}$ gas가 발생하는 차이를 확인하였다(data not shown).

\section{두유 curd 형성 균주의 형태학적 분류}

선별된 균주들을 동정하여 L. mesenteroides로 나타난 균주 를 대표하는 strain No. 2-15-2, 2-19-2와 분자생물학적, 생화학 적 동정 결과 L saker를 대표하는 균주 strain No. 3-8-1, 3-17-1 를 gram staining하여 현미경으로 관찰한 결과, 모두 gram positive로 보라색으로 염색되는 것을 볼 수 있었으며 L. mesenteroides는 구균, L. sakei는 간균으로 확인할 수 있었다(data not shown). 또한 전자현미경으로 관찰한 결과, L. mesenter-

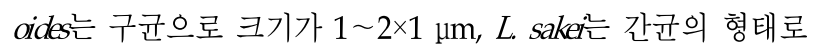

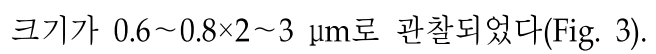

두유 curd 형성균주의 whole cell protein pattern 다양성 $16 \mathrm{~S} \mathrm{rDNA}$ 동정에서 L. mesenteroides로 확인되었던 6개의

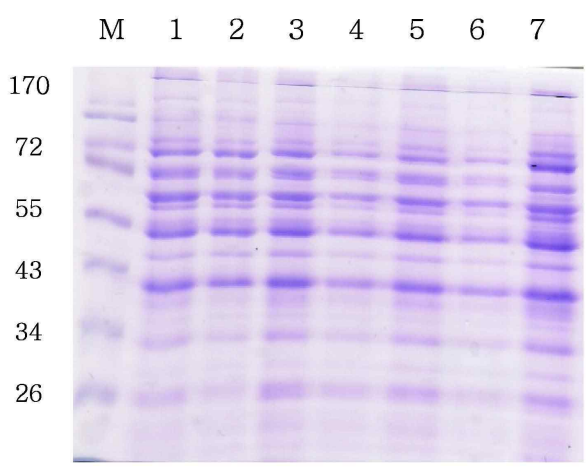

(A)
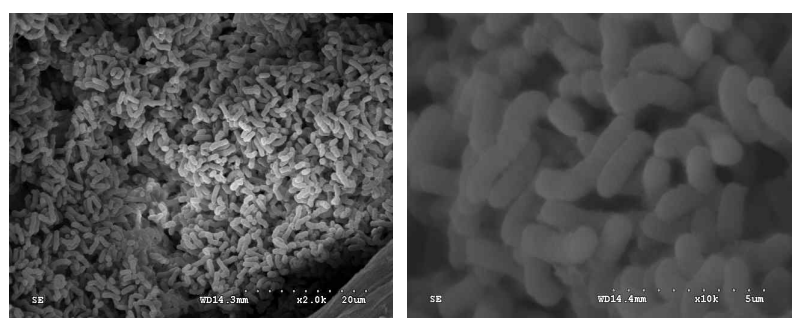

(A)
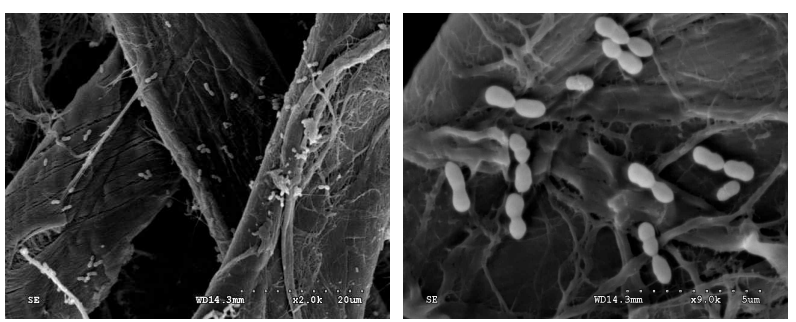

(B)

Fig. 3. SEM micrographs of isolated strain No. 3-17-1 (A) and strain No. 3-4-1 (B) (A: left, $\times 2,000$; right, $\times 10,000)(B$ : left, $\times 2,000$; right, $\times 9,000$ )

균주(strain No. 3-4-1, 4-39-5, 3-4-2, 2-15-2, 2-18-1, 2-19-2)의 whole cell protein의 SDS-PAGE에서의 단백질 band 양상이

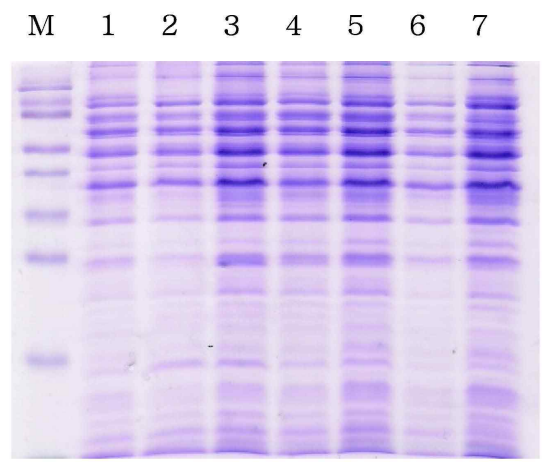

(B)

Fig. 4. SDS PAGE profiles of whole cell proteins of type strain and Leuconostoc mesenteroides isolated from Kimchi. (A) $12 \%$ polyacrylamide gel, (B) 15\% polyacrylamide gel. M : Pagerulaer ${ }^{\mathrm{TM}}$ Prestained Protein ladder, 1: strain No. 2-15-2, 2: strain No. 2-18-1, 3: strain No. 2-19-2, 4: strain No. 3-4-1, 5 : strain No. 3-4-2, 6 : strain No. 4-39-5, 7: Leuconostoc mesenteroides subsp. dextranicum (KCTC 3530) 


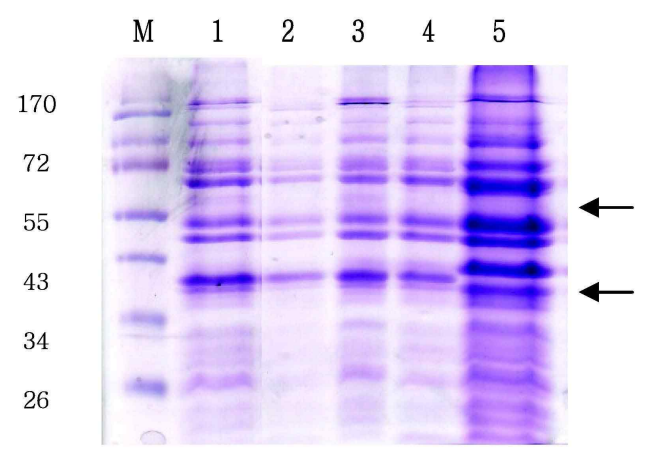

(A)

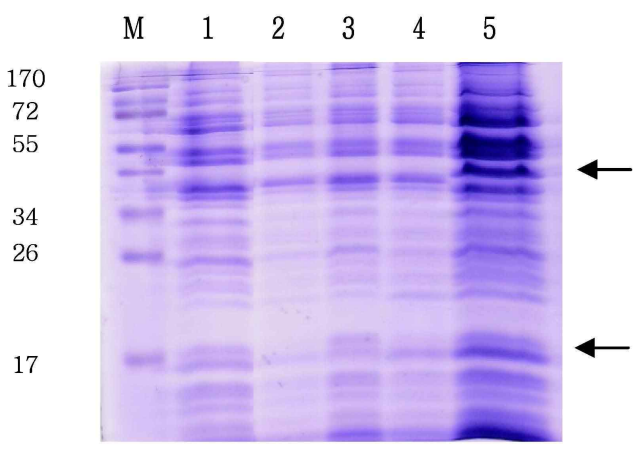

(B)

Fig. 5. SDS PAGE profiles of whole cell proteins of type strain and Lactobacillus sakei isolated from Kimchi. (A) $12 \%$ polyacrylamide gel, (B) 15\% polyacrylamide gel. M : Pagerulaer ${ }^{\mathrm{TM}}$ Prestained Protein ladder, 1: strain No. 2-2-2, 2: strain No. 3-8-1, 3: strain No. 3-8-3, 4: strain No. 3-17-1, 5: Lactobacillus sakei. subsp. sakei (KCTC 3598)

표준균주 L. mesenteroides subsp. dextranicum (KCTC 3530)와 동일한 형태로 나타났다(Fig. 4).

반면, $16 \mathrm{~S} \mathrm{rDNA}$ 를 이용한 동정에서 L. sake로 확인된 균 주 strain No. 3-8-1, 3-17-1, 2-2-2, 3-8-3의 경우 SDS-PAGE에서 의 band 양상이 표준균주 L sakei subsp. sakei (KCTC 3598)와 약 $17 \mathrm{kDa}, 34 \sim 43 \mathrm{kDa}, 60 \mathrm{kDa}$ 부근에서 단백질 band의 차이 가 확인되어 생화학적 분류에서 사용한 탄수화물의 발효 양상 과 같이 다양한 결과를 확인하였다(Fig. 5). 단백질 band를 비 교해 본 결과, $\mathrm{CO}_{2}$ 발생 실험에서 나누어진 group과 동일하게 strain No. 2-2-2, 3-8-3과 strain No. 3-8-1, 3-17-1로 나눌 수 있었다.

\section{감사의 글}

본 논문은 부산대학교 자유과제 학술연구비(2년)에 의하여 연구되었기에 이에 감사드립니다.

\section{References}

1. Aneja, R. P., B. N. Mathur, R. C. Chandan, and S. K. Banerjee. 2002. Cultured/ Fermented products. In: Traditional Indian Milk Products Handbook on Process Technology Modernization for Professionals, Entrepreneurs and Scientists, pp. 158-182, In Gupta, P. R. (ed.), New Delhi, India:Dairy India Publication.

2. Baek, Y. J., C. S. Huh, and J. Y. Lee. 1998. Utilization of fermented milk and it's health promotion. Korean J. Dairy Sci. Technol. 17, 58-71.

3. Chien, H. L., H. Y. Huang, and C. C. Chou. 2006. Transformation of isoflavone phytoestrogens during the fermentation of soymilk with lactic acid bacteria and bifidobacteria. Food Microbiol. 23, 772-778.

4. Choi, Y. B., J. G. Woo, and W. S. Noh. 1999. Hydrolysis of $\beta$-glycosidic bonds of isoflavone conjugates in the lactic acid fermentation of soy milk. Korean J. Food Sci. Technol. 31, 189-195.

5. Hendrich, S., W. Lee, X. Xu, J. H. Wang, and P. A. Murphy, 1994. Defining food component as new nutrient. J. Nutr. 124, 1789-1792.

6. Karleskind, D., I. Laye, E. Halpin, and C. V. Morr. 1991. Improving acid production in soy based yogurt by adding cheese whey proteins and mineral salts. J. Food Sci. 56, 999-1001.

7. Kim, T. W., S. H. Jung, J. Y. Lee, S. K. Choi, S. H. Park, J. S. Jo, and H. Y. Kim. 2003. Identification of lactic acid bacteria in Kimchi using SDS-PAGE profiles of whole cell proteins. J. Micrbiol. Biotechnol. 13, 119-124.

8. Lee, H. P., L. Gourley, S. W. Duffy, J. Esteve, J. Lee, and N. E. Day. 1991. Dietary effects on breast-cancer risk in Singapore. Lancet 337, 197-200.

9. Lim, S. J., Y. T. Kho, and J. C. Yoo. 1984. Manufacture of yogurt from soy protein concentrate. Food Sci. Biotechnol. 16, 143-148.

10. MacGregor, G., A. J. Smith, B. Thakker, and J. Kinsella. 2002. Yoghurt biotheraphy contraindicated in immunosuppressed patients? Postgrad Med J. 78, 366-367.

11. Mann, G. V. and A. Spoerry. 1974. Studies of a surfactant and cholesteremia in the massi. Am J. Clin. Nutr. 27, 464-469.

12. Messina, M. 1995. Modern applications for an ancient bean: soybeans and the prevention and treatment of chronic disease. J. Nutr. 125, 567-569.

13. Messina, M., V. Persky, K. D. R. Setchell, and S. Branes. 1994. Soy intake and cancer risk, A review of the in vitro and in vivo data. Nutr. Cancer 21, 113-131.

14. Mun, S. A. and Y. T. Ko. 1986. Keeping quality of yogurt beverage prepared from soy protein isolate. Food SCi. Biotechnol. 18, 124-129.

15. Schneeman, B. O. 1986. Physical and chemical properties, methods of analysis, and physiological effects. Food Technol. 40, 104-110.

16. Park, K. B. and S. H. Oh. 2007. Production of yogurt with enhanced levels of gamma-aminobutyric acid and valuable 
nutrients using lactic acid bacteria and germinated soybean extract. Bioresource Technol. 98, 1675-1679.

17. Peterson, G. 1995. Evolution of the biochemical targets of genistein in tumor cells. J. Nutr. 125, 784-789.

18. Reddy, G. V., K. M. Shahani, and M. R. Banerjee. 1973. Inhibitory effect of yogurt on Ehrlich ascites tumor cell proliferation. J. NatI. Cancer Inst. 50, 815-817.
19. Wang, Y. C., R. C. Yu, and C. C. Chou. 2006. Antioxidant activities of soymilk fermented with lactic acid bacteria and bifidobacteria. Food Microbiol. 23, 128-135.

20. Yoon, S. Y. and S. J. Hwang. 2005. A survey on the level of recognizing Kimchi among housewives in Seoul Area. Korean J. Food Culture 20, 405-415.

초록 : 두유 커드를 생산하는 김치 유래 젖산균의 동정

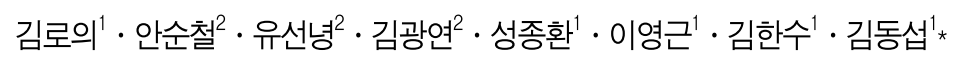

('부산대학교 식품공학과, ${ }^{2}$ 부산대학교 의학전문대학원 미생물학 교실)

본 연구의 목적은 두유 curd를 형성하는 미생물을 분리하는 것이다. 두유 curd를 형성하는 미생물은 채소를 젖산균으로 발효시킨 전통적인 한국의 음식, 김치로부터 분리하였다. 분리 균주 196개 중 10 개의 균주(strain No. 2-2-2, 2-15-2, 2-18-1, 2-19-2, 3-4-1, 3-4-2, 3-8-1, 3-8-3, 3-17-1, 4-39-5)가 단단한 두유 curd를 형성하였고 분자생물 학적 - 생화학적 분석법에 의해 동정되었다. 분리균주로부터 추출한 genomic DNA는 $16 \mathrm{~S} \mathrm{rDNA}$ 지역의 PCR 증 폭을 위한 주형으로 사용하였다. GenBank 데이터로 $16 \mathrm{~S} \mathrm{rDNA}$ 염기서열을 비교한 결과, 분리 균주들은 Leuconostoc mesenteroides group과 Lactobacillus sakei group으로 동정되었다. 두유 curd를 형성하는 균주들의 계통 발생학적 위치와 분류군은 neighbor-joining 방법을 이용하여 확인하였다. 또한, L. mesenteroides group은 생화학 적 특성에 의해 L. mesenteroides subsp. dextranicum으로 동정되었다. 하지만 L. sakei group은 생화학적 특성 비교 시 다양성을 보여 Lactobacillus sp.로 명명하였다. 